\title{
POTENSI DAN PENGELOLAAN SUMBERDAYA \\ IKAN PORA-PORA (Mystacoleucus padangensis Bleeker) DI DANAU TOBA SUMATERA UTARA
}

\author{
Desty W Ginting, Pujiono Wahyu Purnomo, Abdul Ghofar ${ }^{I}$
}

Program Studi Manajemen Sumberdaya Perairan, Jurusan Perikanan

Fakultas Perikanan dan Ilmu Kelautan, Universitas Diponegoro

\begin{abstract}
ABSTRAK
Danau Toba merupakan danau terbesar di Indonesia dan juga merupakan danau vulkanik terbesar di dunia. Danau Toba di Sumatera Utara selama ini menjadi sumber produksi ikan pora-pora (Mystacoleucus padangensis Bleeker). Keberadaan ikan ini cukup membantu perekonomian masyarakat sekitar tetapi kegiatan penangkapan menjadi tidak terkendali sehingga menyebabkan turunnya populasi ikan tersebut. Kondisi yang bersifat kontradiktif ini menyebabkan perlunya dievaluasi kembali jumlah potensi serta pola pengelolaan ikan pora-pora di kawasan Danau Toba Sumatera Utara. Penelitian ini bertujuan untuk mengetahui aspek produksi, aspek biologi, dan aspek pengelolaan sumberdaya ikan pora-pora di Danau Toba. Aspek produksi meliputi trend CPUE dan jumlah produksi. Aspek biologi meliputi panjang berat dan faktor kondisi. Penelitian ini dilaksanakan pada bulan Februari-Maret 2013 di Tempat Pendaratan Ikan (TPI) Tongging. Metode penelitian yang digunakan adalah metode survei dan observasi lapangan. Data yang digunakan adalah data primer dan data sekunder. Data primer terdiri dari panjang total dan berat individu ikan pora-pora yang diperoleh dari lapangan. Data sekunder diambil dari Dinas Kelautan dan Perikanan Provinsi Sumatera Utara berupa jumlah produksi dan jumlah trip penangkapan selama 2 tahun, yaitu 2008 2009. Hasil penelitian menunjukkan diperoleh nilai CPUE alat tangkap doton lebih kecil dibandingkan alat tangkap tanggok dengan nilai $1,64 \mathrm{~kg} / \mathrm{jam}$ dan $4,72 \mathrm{~kg} / \mathrm{jam}$. Pertumbuhan ikan pora-pora bersifat allometric positive dengan nilai $\mathrm{b}$ sebesar 3,31. Faktor kondisi (Kn) ikan pora-pora sebesar 1,028 yang berarti bahwa badan ikan kurus atau kurang montok. Sehingga aspek pengelolaan yang dapat diberikan adalah dengan mengatur mesh size alat tangkap yang tidak lebih kecil dari 1,25 inchi.
\end{abstract}

Kata kunci : Potensi, Pengelolaan, Sumberdaya Ikan Pora-Pora, Danau Toba

\section{ABSTRACT}

Lake Toba is the largest lake in Indonesia and is also a volcanic lakes largest in the world. Lake Toba in North Sumatera recently be a source of fish production pora-pora (Mystacoleucus padangensis Bleeker). The existence of this fish is enough help the economy around but the activities of the catch of being unmanageable so as to cause a drop in the populations of fish. The condition of having the character of contradictory this will cause the need to be evaluated the amount returned the potential dan management pattern fish of pora-pora in the area of Lake Toba in North Sumatera. This research was know the aspect of production, the aspect of biology, an facets of the management of resorces fish of pora-pora in Lake Toba. Aspects of production included production and number of CPUE trends. Biological aspects include the length and weight and the factors of condition. This research was done on February - March 2012 in TPI Tongging. The research used the method of survey and field observation. Data used was primary and secondary data. Primary data consisted of a total length and weight in individual fish of pora-pora obtained from the field. Secondary data was taken from the Department of Marine and Fisheries of the Province of North Sumatera. Numbers of production and numbers of catch was calculated from 2 years trip namely $2008-2009$. The result obtained value of CPUE of doton was smaller than that in tanggok with value was $1.64 \mathrm{~kg} / \mathrm{hour}$ and $4.72 \mathrm{~kg} /$ hour. Fish growth was positive allometric with value of $\mathrm{b}$ was 3.31 . Factor condition $(\mathrm{Kn})$ of porapora was 1.028 which means that body bony fish or less fat. Aspect of management therefore that can be given iwas to set up the mesh size the capture tools is not smaller than 1.25 inchi.

Key words : potential, management, pora-pora fish resourch, Lake Toba 


\section{Pendahuluan}

Menurut Hehanusa (2000), Danau Toba merupakan danau terbesar di Indonesia. Danau Toba juga merupakan danau vulkanik terbesar di dunia dengan luas $1.130 \mathrm{~km}^{2}$ dan titik terdalam $529 \mathrm{~m}$ dengan kategori sebagai danau oligotrofik dengan ciri khas miskin akan unsur hara, memiliki waktu tinggal yang cukup lama, hampir tidak ada arus dan suhu stabil. Perairan Danau Toba dimanfaatkan untuk kegiatan perikanan, pertanian, pemukiman, peternakan dan pariwisata. Khusus untuk kegiatan perikanan telah dimulai sejak tahun 1986 dan terus mengalami peningkatan yang tajam hingga kini.

Danau Toba di Sumatera Utara selama ini menjadi sumber produksi ikan pora-pora (Mystacoleucus padangensis Bleeker.). Keberadaan ikan yang merupakan hasil penebaran (restocking) di era pemerintahan Presiden Megawati Soekarno Putri ini cukup membantu perekonomian penduduk sekitar danau, tetapi kegiatan penangkapan ikan pora-pora menjadi tak terkendali. Karena adanya kegiatan penangkapan itu pula, maka kondisi Danau Toba saat ini cukup memprihatinkan.

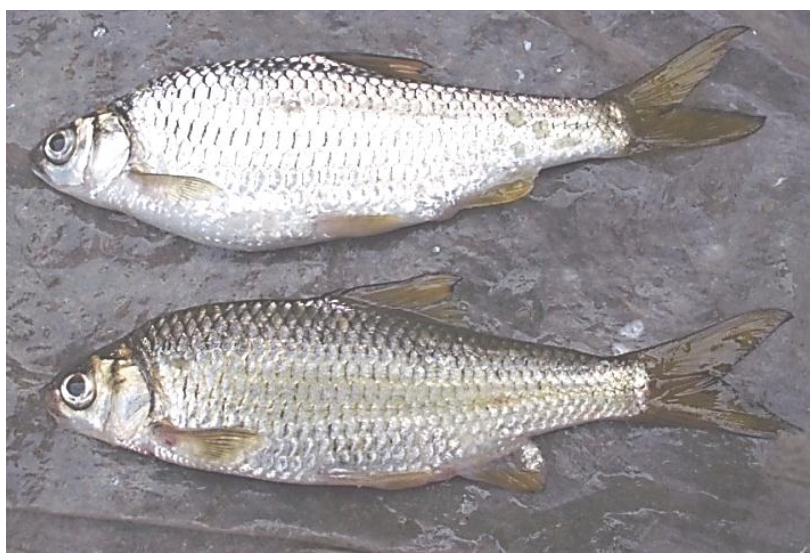

Gambar 1. Ikan Pora-Pora (Sumber: Dokumentasi, 2013)

Walaupun telah dilakukan kajian tentang bioekologi termasuk kesesuaian untuk pemakanan, pemijahan, asuhan dan pembesaran ikan pora-pora sampai dengan kemungkinan dampaknya terhadap populasi ikan asli dan hasil tangkapan tetapi umumnya masyarakat masih mempertanyakan keberadaan dan pertumbuhan ikan pora-pora yang sangat cepat apakah dapat merusak ekosistem perairan Danau Toba mengingat ikan pora-pora yang ditebar tersebut bukan spesies ikan asli perairan Danau Toba. Pertanyaan tersebut muncul akibat sangat terbatasnya informasi bioekologi ikan yang hidup di perairan Danau Toba. Dengan demikian kajian bioekologi ikan pora-pora sangat perlu dilakukan agar tercapai pengelolaaannya yang berkelanjutan di perairan Danau Toba.

Tujuan dilakukannya penelitian ini adalah sebagai berikut:

1. Untuk mengetahui aspek produksi yang meliputi analisa produksi per unit upaya penangkapan (CPUE) dan jumlah produksi ikan pora-pora yang terdapat di Danau Toba Sumatera Utara;

2. Untuk mengetahui aspek biologi ikan pora-pora yang meliputi komposisi ukuran panjang dan berat, serta faktor kondisi; dan

3. Untuk mengetahui aspek pengelolaan sumberdaya ikan pora-pora di Danau Toba.

Penelitian ini dilaksanakan pada bulan Februari-Maret 2013 yang berlokasi di TPI Tongging. Hasil penelitian ini diharapkan dapat menambah informasi dan pengetahuan kepada pemerintah dan masyarakat sekitar tentang pentingnya pengelolaan sumberdaya perikanan agar kelestarian sumberdaya, khususnya ikan pora-pora di Danau Toba Sumatera Utara dapat tetap terjaga.

\section{Materi dan Metode Penelitian}

\section{A. Materi Penelitian}

Materi yang digunakan dalam penelitian ini adalah ikan pora-pora (Mystacoleucus padangensis Bleeker) yang diperoleh dari TPI Tongging. Alat yang digunakan dalam penelitian ini adalah penggaris dengan ketelitian $5 \mathrm{~mm}$ yang digunakan untuk mengukur panjang ikan pora-pora (Mystacoleucus padangensis Bleeker). Pengukuran berat ikan pora-pora (Mystacoleucus padangensis Bleeker) dilakukan dengan menggunakan timbangan dengan ketelitian 10 gr. Peralatan lain yang digunakan adalah kamera digital, alat tulis, kuisioner nelayan, tisu, dan kalkulator.

\section{B. Metode Penelitian}

Metode yang dilakukan dalam penelitian ini adalah metode survei, dimana menurut Notoatmodjo (2002), survei adalah cara penelitian deskriptif yang dilakukan terhadap sekumpulan objek yang biasanya cukup banyak dalam jangka waktu tertentu. Pada umumnya, survei bertujuan untuk membuat penilaian 
terhadap suatu kondisi dan penyelenggaraan suatu program di masa sekarang, kemudian hasilnya digunakan untuk menyusun perencanaan perbaikan program tersebut. Pengumpulan data dilakukan dengan menggunakan metode observasi, dimana menurut Narbuko (2009) metode observasi dilakukan dengan pengamatan langsung dan pencatatan secara sistematis kejadian-kejadian yang diselidiki.

\section{Penentuan lokasi dan pengambilan sampel}

Lokasi pengambilan sampel adalah Tempat Pendaratan Ikan di Desa Tongging. Pemilihan lokasi sampling tersebut berdasarkan jumlah produksi, dimana TPI Tongging merupakan TPI penghasil ikan porapora terbanyak dibandingkan TPI lain yang terdapat di sekitar Danau Toba. Pengambilan sampel dilakukan dengan mengambil seluruh hasil tangkapan ikan pora-pora untuk aspek biologi. Sampel ikan diambil secara acak sebanyak $10 \%$ dari seluruh hasil tangkapan pada satu kapal sampel kemudian dilakukan pengukuran. Pengukuran sampel ikan dilakukan saat setelah selesai melakukan penangkapan setiap hari dalam 1 bulan.

\section{Pengumpulan data}

Jenis data yang digunakan dalam analisis data berupa data primer dan data sekunder. Data Sekunder diperoleh dari data statistik Dinas Kelautan dan Perikanan Sumatera Utara. Data primer diperoleh dari hasil penelitian di lapangan. Inventarisasi data yang dilakukan antara lain adalah:

1. Data primer yang diambil adalah data hasil wawancara dengan nelayan dan melakukan pengamatan langsung terhadap hasil tangkapan ikan pora-pora di TPI Tongging, menghitung panjang dan berat ikan pora-pora, dan menghitung faktor kondisi ikan pora-pora.

- Panjang total ikan pora-pora

Sampel ikan pora-pora (Mystacoleucus padangensis Bleeker) dikeringkan permukaan tubuhnya dengan menggunakan tisu lalu ukur panjang total ikan menggunakan penggaris.

- Berat individu ikan pora-pora

Berat dari masing-masing ikan diukur menggunakan timbangan dengan ketelitian alat $10 \mathrm{gr}$ (gram).

2. Data sekunder

Pengambilan data sekunder yang dikumpulkan adalah data alat tangkap ikan pora-pora dan data produksi yang diperoleh dari Dinas Kelautan dan Perikanan Sumatera Utara.

3. CPUE (Catch per Unit Effort)

CPUE merupakan hasil tangkapan ikan per jenis alat tangkap dibagi dengan upaya penangkapan. Alat tangkap yang digunakan untuk menangkap ikan pora-pora di Danau Toba ada 2 jenis, yaitu doton dan tanggok. Pengamatan hasil tangkapan per jenis alat tangkap dilakukan setiap hari setelah proses penangkapan dan penjualan selesai. Pengamatan langsung jumlah upaya penangkapan ikan pora-pora juga dilakukan setiap hari. Metode ini digunakan untuk menduga besarnya populasi yang situasinya tidak praktis untuk mendapat jumlah yang pasti dari individu ikan tersebut dalam satu unit area (Effendi, 1997).

Dasar penghitungan, yaitu :

$$
\text { CPUE }=\frac{\text { produksi peralat tangkap }}{\text { tripper alat tangkap }}
$$

\section{Metode Analisis Data}

\section{Ukuran pertama kali tertangkap}

Menurut Saputra (2009), $\mathrm{L}_{\mathrm{C} 50 \%}$ disebut juga sebagai ukuran ikan yang pertama kali tertangkap jaring. Apabila ukuran mata jaring diketahui dan ukuran ikan yang pertama kali tertangkap $\left(\mathrm{L}_{\mathrm{C} 50 \%}\right)$ diketahui, maka faktor seleksi alat tangkap juga diketahui. Ukuran panjang ikan pertama kali tertangkap $\mathrm{L}_{\mathrm{C} 50 \%}$ diperoleh melalui plotting antara persentase frekuensi kumulatif ukuran ikan dengan ukuran ikan itu sendiri. Apabila dari titik potong antara kurva dengan titik $50 \%$ yang ditarik vertikal memotong sumbu x (panjang), maka akan diperoleh ukuran rata-rata 50\% ikan yang tertangkap. Nilai tersebut akan menjelaskan bahwa 50\% ikan yang tertangkap kurang dari ukuran mesh size alat tersebut dan 50\% lainnya berukuran lebih besar dari ukuran tersebut.

\section{Ukuran $\mathbf{L}$ infinite $\left(\mathbf{L}_{\infty}\right)$}

Menurut Pauly dalam Saputra (2009), nilai dugaan awal $\mathrm{L}_{\infty}$ dapat diketahui dengan beberapa cara. Salah satunya adalah dengan rumus:

Dimana:

$$
\mathrm{L} \infty=\frac{\mathrm{L} \max }{0,95}
$$

L max : ukuran maksimum ikan yang tertangkap

\section{Hubungan panjang-berat}

Data yang diperoleh disusun dalam tabel kisaran antara panjang dan berat tubuh ikan. Dari data tersebut di buat grafik scatter plot untuk mengetahui persebaran data tersebut. Menurut Saputra (2009) hubungan panjang dan berat ikan dapat dicari dengan menggunakan persamaan di bawah ini :

$$
W=a L^{b}
$$


Dimana :

W : berat (gr)

L : panjang total $(\mathrm{mm})$

a : intercept

b : slope

Persamaan tersebut dapat digambarkan dalam bentuk linier dengan cara dilogaritmakan, sehingga persamaan menjadi $\log \mathrm{W}=\log \mathrm{a}+\mathrm{b} \log \mathrm{L}$. Pendugaan pertumbuhan panjang berat dilakukan dengan cara membuat grafik simulasi berdasarkan persamaan pertumbuhan panjang.

Untuk mengetahui berbeda atau tidak nilai b perlu menggunakan uji t (t-test) dengan hipotesis:

$\mathrm{H}_{0}$ : Nilai $\mathrm{b}=3$, sehingga pertumbuhan bersifat isometric

$\mathrm{H}_{1}$ : Nilai $\mathrm{b} \neq 3$, sehingga pertumbuhan bersifat allometric

Jika $\mathrm{b}=3$, maka pertumbuhannya isometric, yaitu tingkat pertumbuhan panjang, lebar dan tinggi ikan adalah sama (Everhart dan Youngs, 1981). Jika tidak sama dengan 3, pertumbuhannya allometric, yaitu allometric positive apabila $\mathrm{b}>3$ dan allometric negative apabila $\mathrm{b}<3$.

Kaidah pengambilan keputusan :

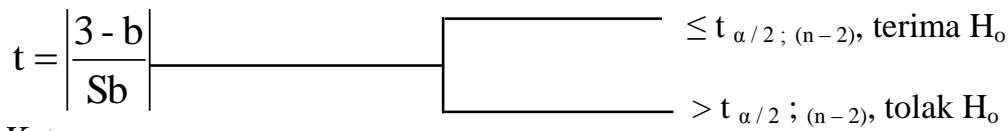

Keterangan:

$$
\begin{aligned}
\mathrm{t} & =\text { nilai } \mathrm{t} \text { hitung } \\
\mathrm{b} & =\text { slope } \\
\mathrm{Sb} & =\text { standar deviasi }
\end{aligned}
$$

Untuk pengujian nilai $\mathrm{b}$ dengan menggunakan uji $\mathrm{t}$ dimana :

$\mathrm{t}$ hitung $>\mathrm{t}$ tabel $\rightarrow$ tolak $\mathrm{H}_{\mathrm{o}}$, pertumbuhan ikan allometric

t hitung $\leq \mathrm{t}$ tabel $\rightarrow$ terima $\mathrm{H}_{\mathrm{o}}$, pertumbuhan ikan isometric

\section{Faktor kondisi}

Perhitungan faktor kondisi berdasarkan pada panjang dan berat. Menurut Effendie (2002) dapat dirumuskan:

$$
\mathrm{Kn}=\frac{W}{a L^{b}}
$$

Dimana :

Kn : Faktor Kondisi

W : berat rata-rata ikan (gram)

L : panjang rata-rata ikan $(\mathrm{mm})$

$\mathrm{a}$ dan $\mathrm{b}$ : konstanta

Nilai Kn berkisar antara $2-4$ menyatakan bahwa badan ikan agak pipih sedangkan apabila nilai Kn berkisar antara 1 - 3 berarti bahwa badan ikan kurang pipih. Nilai faktor kondisi akan lebih penting dan lebih bermakna jika dibandingkan antar ukuran atau antar lokasi, karena jika terpaku hanya kepada satu nilai FK tidak banyak artinya, atau bahkan tidak ada (Saputra, 2009).

\section{Selektivitas alat tangkap}

Menurut Saputra (2009), pada dasarnya, semua alat tangkap memiliki selektivitas terhadap ikan. Selektivitas alat tangkap dapat diartikan sebagai kemampuan suatu alat tangkap didalam menyeleksi hasilhasil tangkapan. Nilai selektivitas alat tangkap (SF) dapat dihitung dengan mengetahui nilai L $\infty$ dan mesh size alat tangkap yang digunakan. Rumus yang digunakan dalam mencari nilai selektivitas alat tangkap adalah sebagai berikut:

$$
S F=\frac{\mathrm{L} 50 \%}{\text { mesh size }}
$$

Faktor seleksi alat tangkap dan ukuran ikan saat pertama kali tertangkap alat penting diketahui karena sangat penting bagi pengelolaan perikanan. Hal ini dapat digunakan untuk pendugaan awal selektivitas alat tangkap yang digunakan. Apabila faktor seleksi alat tangkap telah diperoleh, maka dapat dirumuskan saran tindak lanjut pengelolaan, khususnya terkait dengan pengaturan mata jaring alat tangkap (Ricker, 1975).

\section{Hasil dan Pembahasan}

Tempat Pendaratan Ikan (TPI) Tongging tempat dilakukannya sampling terbentang pada pantai sepanjang lebih kurang 6,5 km dari koordinat 2'53'04.1''LU/98'31'30,9' 'BT $2^{\circ} 52^{\prime} 26,5^{\prime \prime} \mathrm{LU} / 98^{\circ} 32^{\prime} 31,0^{\prime}$ 'BT. TPI Tongging terletak di Kabupaten Karo, Kecamatan Merek. Jarak terdekat pemukiman terhadap garis pantai adalah 0 meter. Pembuangan limbah cair rumah tangga tersalur ke Danau Toba dan meresap ke dalam tanah. Terdapat keramba jaring apung milik masyarakat berjumlah 88 unit. Kedalaman danau pada lokasi keramba kurang dari 23 meter. Jarak keramba dari garis pantai adalah 2 meter. 


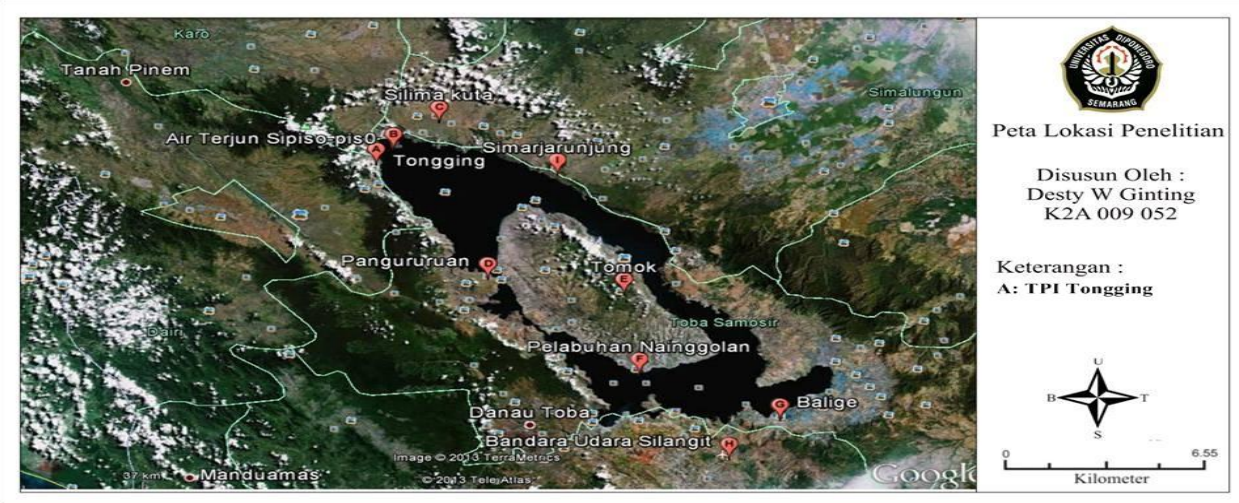

Gambar 2. Peta Danau Toba

\section{Analisa Produksi}

\section{a. Alat Tangkap Ikan Pora-Pora}

Alat tangkap yang digunakan untuk menangkap ikan pora-pora di Danau Toba terdiri dari beberapa jenis, yaitu doton/ jaring insang (sejenis alat tangkap Gill net), tanggok (sejenis alat tangkap sero atau Scoop net), dan juga anco. Berdasarkan hasil pengamatan di lapangan dapat diketahui bahwa, alat tangkap yang dipergunakan adalah alat tangkap doton dan tanggok. Hal tersebut dikarenakan, mayoritas nelayan sekitar menggunakan alat tangkap tersebut sebagai alat tangkap khusus ikan pora-pora di Danau Toba sekitar TPI Tongging.

Alat tangkap doton yang digunakan berukuran panjang $50 \mathrm{~m}$ dengan mesh size $1 \frac{1 / 4}{4}$ inchi. Pengoperasian alat tangkap doton dilakukan mulai sore hari. Daerah fishing ground masing-masing nelayan berbeda, kira-kira berjarak antara $10-40 \mathrm{~m}$ dari pinggir danau. Fishing ground dari masing-masing nelayan tidak berpindah-pindah karena setiap nelayan sudah memiliki fishing ground sendiri. Nelayan menuju fishing ground sekitar pukul 17.00 - 19.00 WIB. Setibanya di fishing groud yang telah ditentukan maka yang pertama diturunkan adalah pelampung, selanjutnya dilakukan penurunan jaring (setting). Setelah semua jaring telah diturunkan dan telah terentang dengan sempurna, maka jaring dibiarkan sampai esok hari kemudian. Proses penarikan jaring (hauling) dilakukan keesokan harinya sekitar pukul 06.30-07.30 WIB. Pada saat melakukan hauling, jaring diatur dengan baik seperti semula.

Alat tangkap tanggok memiliki mesh size yang sangat rapat yaitu berukuran 3/4 inchi. Alat tangkap tanggok dalam kegiatan penangkapannya menyerupai perangkap. Teknik penangkapannya dilakukan di aliran air sungai. Hal tersebut dilakukan bertujuan untuk menghalangi proses ruaya ikan pora-pora dari Danau Toba menuju sungai Sipiso-piso. Oleh karena itu, dapat diketahui bahwa ikan pora-pora yang tertangkap merupakan ikan pora-pora yang belum matang gonad. Hal ini mengakibatkan terjadinya penurunan jumlah populasi dan ukuran dari ikan pora-pora. Penurunan jumlah populasi ini dapat mengakibatkan terjadinya penurunan jumlah hasil tangkapan nelayan.

Adanya perbedaan jumlah hasil tangkapan dari alat tangkap doton disebabkan karena adanya perbedaan lokasi penangkapan (fishing ground). Sampel perahu yang menggunakan alat tangkap doton yang diambil dalam penelitian ini ada sebanyak 3 unit dengan fishing ground yang berbeda-beda. Perahu tangkap yang pertama melakukan penangkapan ikan pora-pora di Danau Toba dengan jarak $35 \mathrm{~m}$ dari pinggir Danau Toba. Fishing ground-nya terletak di daerah aliran air sungai. Perahu tangkap yang kedua menangkap ikan dengan jarak $5 \mathrm{~m}$ dari pinggir Danau Toba. Sedangkan perahu tangkap yang ketiga memiliki fishing ground yang berjarak $30 \mathrm{~m}$ dari pinggir Danau Toba. Fishing ground perahu tangkap kedua dan ketiga pada tempat jauh dari aliran air sungai.

Penangkapan ikan pora-pora dengan alat tangkap tanggok dilakukan dengan periode tangkap di aliran Sungai Sipiso-piso sebanyak 2 kali dalam sehari. Hal tersebut dapat menurunkan jumlah produksi ikan porapora karena proses penangkapannya dilakukan di aliran sungai. Hal tersebut disebabkan karena ikan porapora yang tertangkap merupakan ikan yang akan memijah seperti yang dikemukakan oleh Kartamihardja (2010) bahwa ikan pora-pora akan beruaya ke daerah sungai untuk memijah setiap hari. Hal ini dapat mengakibatkan menurunnya jumlah produksi.

Jumlah produksi ikan pora-pora yang ditangkap dengan alat tangkap doton pada bulan Februari hingga Maret saat penelitian dapat dilihat pada Gambar 2. 


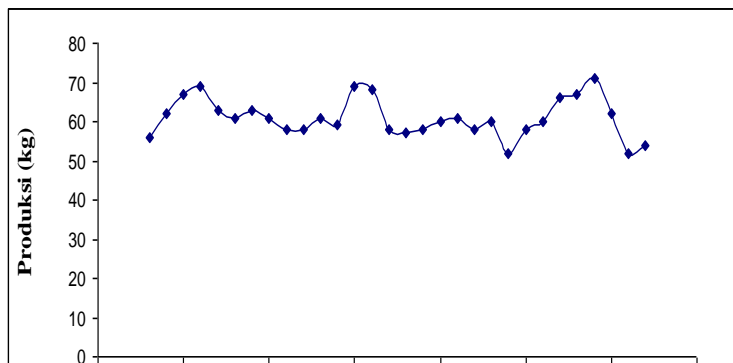

20/02/2013 25/02/2013 02/03/2013 07/03/2013 12/03/2013 17/03/2013 22/03/2013 27/03/2013

Waktu Penangkapan

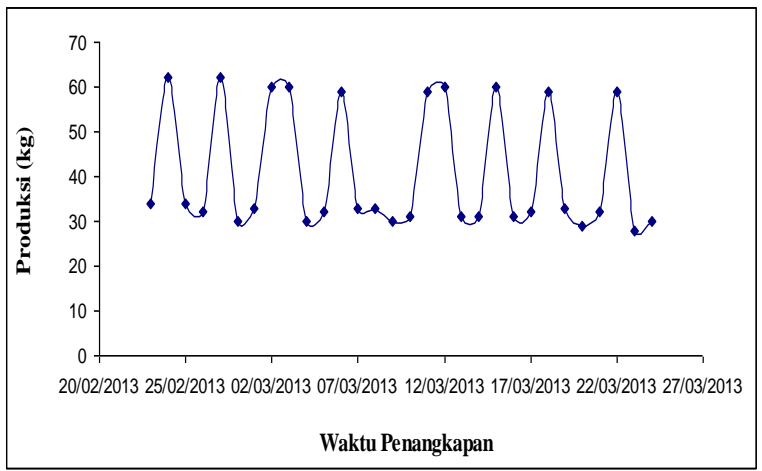

Waktu Penangkapan

Gambar 3. Grafik Jumlah Produksi Alat Tangkap (Kiri: Doton; Kanan: Tanggok)

Dari Gambar 3, dapat diketahui bahwa jumlah hasil produksi ikan pora-pora di Danau Toba yang ditangkap dengan menggunakan alat tangkap doton lebih stabil. Jumlah produksi rata-rata harian alat tangkap doton adalah sebanyak $61 \mathrm{~kg}$ ikan pora-pora dengan jumlah produksi terkecil sebanyak $52 \mathrm{~kg}$ dan produksi terbanyak $71 \mathrm{~kg}$. Dari grafik diketahui bahwa terjadi peningkatan jumlah produksi ikan pora-pora dari tanggal $16-21$ Maret, akan tetapi terjadi pula penurunan jumlah tangkap yang drastis pada tanggal $21-23$ Maret. Hal tersebut terjadi karena pada saat proses penangkapan terjadi hujan di sekitar Danau Toba yang mengakibatkan kondisi perairan menjadi keruh dan suhu perairan menjadi lebih dingin. Menurut Kartamihardja (2010), ikan pora-pora menyukai perairan yang jernih dan suhu perairan sekitar $26-28^{\circ} \mathrm{C}$. Hal lain yang menyebabkan menurunnya jumlah produksi ikan pora-pora adalah faktor cahaya bulan yang terang pada malam hari saat proses penangkapan. Berdasarkan hasil wawancara dengan nelayan sekitar, apabila cahaya bulan penuh pada malam hari, maka jumlah produksi akan menurun. Hal tersebut sesuai dengan pernyataan Kartamihardja dan Sarnita (2010) dimana hasil tangkapan umumnya menurun sampai $50 \%$ pada saat bulan terang. Hal ini dikarenakan cahaya bulan menyebar pada malam hari sehingga ikan pora-pora pun ikut menyebar. Oleh karena itulah, hasil tangkapan menurun.

Pengoperasian alat tangkap tanggok dilakukan di muara Sungai Sipiso-piso Tongging. Dimana menurut Purnomo dan Kartamihardja (2008), bahwa Sungai Sipiso-piso merupakan habitat pemijahan ikan pora-pora. Dari Gambar 3 diketahui bahwa hasil produksi ikan pora-pora yang ditangkap dengan menggunakan alat tangkap tanggok diperoleh data yang menunjukkan bahwa jumlah produksi ikan pora-pora berubah-ubah. Rata-rata jumlah tangkapan harian dengan menggunakan alat tangkap tanggok adalah sebanyak $41 \mathrm{~kg}$. Hal ini disebabkan karena faktor lamanya penangkapan (effort). Semakin lama kegiatan penangkapan berlangsung, maka akan semakin banyak jumlah ikan yang ditangkap. Akan tetapi, penggunaan alat tangkap tanggok dapat merusak kelestarian ikan pora-pora karena pengaplikasiannya yang terdapat di muara sungai sehingga spawning stock (sediaan yang siap memijah) akan berkurang karena tidak mampu menghasilkan anak-anak ikan/recruitment di masa mendatang.

Pengaplikasian alat tangkap doton yang mobile lebih ramah lingkungan dibandingkan alat tangkap tanggok. Hal ini dikarenakan, ikan sasaran alat tangkap doton dapat dikategorikan sebagai ikan dewasa dan cukup umur untuk ditangkap. Pengaplikasian alat tangkap doton dilakukan di tengah danau. Sedangkan ikan sasaran alat tangkap tanggok adalah ikan-ikan yang hendak memijah. Sekilas mata dapat dilihat bahwa ukuran ikan yang tertangkap dengan alat tangkap doton lebih besar dibandingkan ukuran ikan yang ditangkap dengan alat tangkap tanggok. Ukuran panjang ikan yang tertangkap saat penelitian adalah antara $10-17,5$ $\mathrm{cm}$ dengan berat ikan yang tertangkap berkisar antara $10-80$ gr. Apabila penangkapan ikan pora-pora dengan alat tangkap tanggok terus-menerus dilakukan dan jumlah upaya penangkapan ditingkatkan, maka dapat mengakibatkan berkurangnya stok ikan di perairan. Karena penangkapan dengan alat tangkap tanggok mengakibatkan ikan pora-pora tidak dapat memijahkan telur-telurnya.

\section{CPUE Ikan Pora-Pora di TPI Tongging}

Usaha penangkapan ikan pora-pora dengan menggunakan alat tangkap doton dan tanggok di Danau Toba sudah berlangsung sejak tahun 2005. Untuk memperoleh hasil produksi yang maksimal, maka dilakukan upaya penangkapan dengan tujuan untuk mendapatkan hasil tangkapan yang sebanyak-banyaknya. Namun dalam hal ini tetap harus menghindari tata cara dan perilaku penangkapan yang merusak agar tidak mempercepat rusaknya ekosistem dan keanekaragaman hayati. Setiap alat tangkap memiliki produktifitas atau kemampuan untuk menangkap ikan sasaran yang berbeda-beda. Jumlah produksi ikan yang tertangkap dikenal dengan istilah CPUE (Catch Per Unit Effort).

Hasil penelitian yang diperoleh dari perhitungan CPUE dan upaya penangkapan yang dilakukan para nelayan yang ada di TPI Tongging, Danau Toba adalah sebagai berikut: 


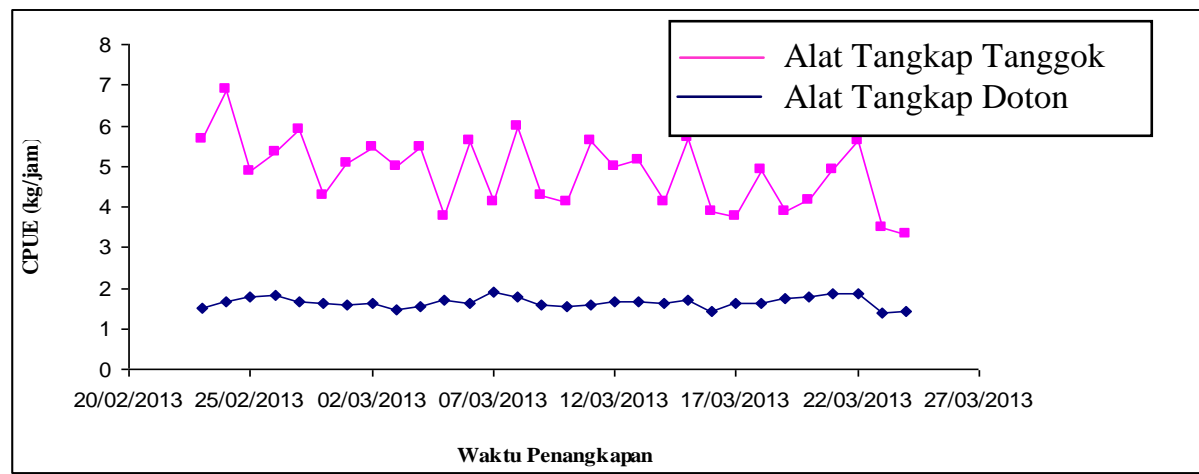

Gambar 4. Grafik Trend CPUE Alat Tangkap Doton dan Tanggok

Berdasarkan Gambar 4 tentang Trend CPUE kedua alat tangkap tersebut maka diperoleh keterangan bahwa trend CPUE alat tangkap tanggok lebih besar dibandingkan trend CPUE alat tangkap doton. Hal tersebut berarti bahwa nilai CPUE rata-rata pada alat tangkap tanggok lebih tinggi dibandingkan dengan alat tangkap doton. Perbedaan ini diperkirakan disebabkan karena tingginya jumlah produksi pada alat tangkap tanggok. Lokasi pengaplikasian alat tangkap yang dilakukan di daerah aliran sungai memperoleh jumlah produksi ikan yang lebih tinggi dibandingkan dengan lokasi penangkapan dengan alat tangkap doton. Jumlah lamanya penangkapan juga sangat mempengaruhi tingginya nilai CPUE. Meskipun demikian, maka sebagai acuan nilai CPUE yang dipergunakan dalam penelaahan lebih lanjut adalah nilai CPUE dari penggunaan alat tangkap doton. Hal ini disebabkan karena alat tangkap doton dipergunakan sebagai alat tangkap aktif di lingkungan perairan Danau Toba.

Hasil perhitungan CPUE berdasarkan penangkapan ikan pora-pora dengan menggunakan alat tangkap doton di Kab. Karo hanya tersedia pada tahun 2008 - 2009. Hasilnya adalah seperti pada Tabel 3 Gambar 5 berikut ini:

Tabel 3. Data Statistik CPUE Alat Tangkap Doton di TPI Tongging selama 2 Tahun

\begin{tabular}{cccc}
\hline Tahun & Jumlah produksi $(\mathrm{kg})$ & jumlah trip & CPUE $(\mathrm{kg} /$ trip $)$ \\
\hline 2008 & 509.000 & 86415 & 5,89 \\
2009 & 940 & 1080 & 870,37 \\
\hline
\end{tabular}

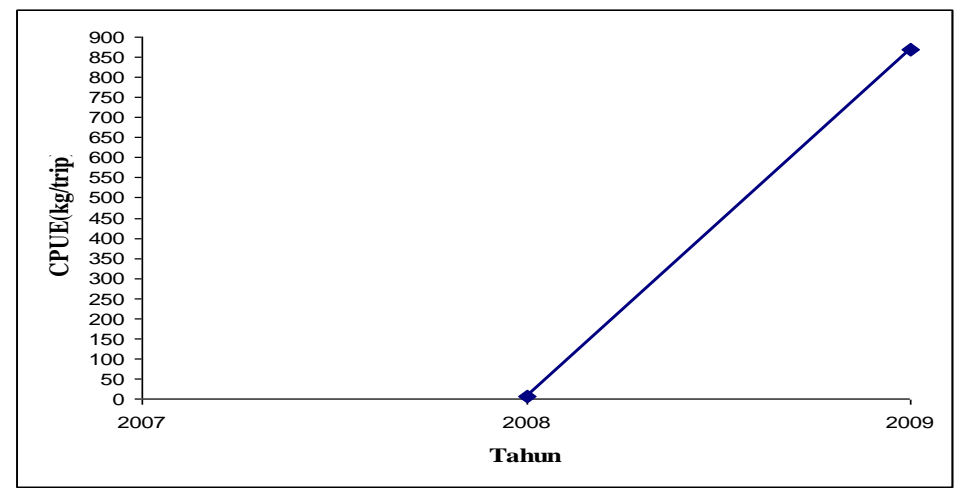

Gambar 5. Grafik CPUE Tahun 2008 - 2009 Alat Tangkap Doton di Kab. Karo

Hasil perhitungan CPUE yang diperoleh dari data lapangan dan data statistik DKP Provinsi Sumatera Utara didapatkan hasil bahwa nilai CPUE yang diperoleh dari lapangan lebih besar daripada nilai CPUE yang diperoleh dari DKP. Hal ini disebabkan karena tingginya jumlah produksi yang dihasilkan.

Hasil data DKP diketahui bahwa terjadi penurunan jumlah trip penangkapan dari tahun 2008 ke tahun 2009 sehingga terjadi pula peningkatan jumlah produksi pada tahun yang sama. Hal tersebut mengakibatkan terjadinya peningkatan nilai CPUE pada tahun 2009. Sesuai dengan pernyataan Ali (2007), bahwa penurunan jumlah unit upaya penangkapan (effort) biasanya selalu diikuti dengan peningkatan jumlah tangkapan per unit upaya (CPUE), demikian pula sebaliknya bahwa peningkatan jumlah unit alat tangkapan diikuti oleh penurunan jumlah alat tangkapan per unitnya.

Menurut Badrudin (2010), hasil tangkapan per-satuan upaya (CPUE) adalah salah satu indikator bagi status sumberdaya ikan yang merupakan ukuran dari kelimpahan relatif, sedangkan tingkat produksi dapat merupakan indikator kinerja ekonomi. Diperolehnya gambaran tentang trend CPUE dari suatu perikanan dapat merupakan salah satu indikator tentang 'sehat nya' suatu perikanan. Trend CPUE yang menaik merupakan gambaran bahwa tingkat eksploitasi sumberdaya ikan dapat dikatakan masih pada tahapan berkembang. Dari hasil trend CPUE stok sumberdaya perikanan ikan pora-pora di TPI Tongging berdasarkan data statistik Perikanan pada periode 2008 - 2009 dapat diduga bahwa status pemanfaatannya masih pada 
tahap berkembang. Oleh karena itu, pengembangan pemanfaatan sumberdaya ikan pora-pora masih terbuka luas untuk dimanfaatkan mengingat tingkat pemanfaatan saat ini masih dalam tahap berkembang akan tetapi harus tetap disertai dengan pemantauan CPUE secara berlanjut.

\section{Aspek Biologi}

\section{a. Analisa Panjang dan Berat}

Hasil pengukuran secara total analisa panjang berat dalam penelitian ini didasarkan pada 10.486 ekor ikan pora-pora dengan ukuran yang berbeda-beda. Dimana panjang total terendah dari ikan pora-pora yang tertangkap adalah sebesar $100 \mathrm{~mm}$ dan panjang total tertinggi adalah $175 \mathrm{~mm}$. Hasil perhitungan diperoleh nilai hubungan panjang dan berat ikan pora-pora dengan nilai a (intercept) yaitu sebesar 0,00000324 dan b (slope) sebesar 3,31.

Berdasarkan hasil perhitungan diperoleh persamaan logaritma yaitu $\mathrm{W}=0,00000324 \mathrm{~L}^{3,31}$. Hasil perhitungan uji $\mathrm{t}$ diperoleh bahwa nilai $\mathrm{t}$ hitung lebih besar daripada $\mathrm{t}$ tabel yang berarti bahwa pertumbuhan ikan allometric. Hasil perhitungan didapatkan pula bahwa $\mathrm{b}>3$ dimana nilai $\mathrm{b}$ adalah 3,31. Hasil yang diperoleh tidak berbeda jauh dengan hasil penelitian Kartamihardja dan Sarnita (2010) dimana nilai b (slope) diperoleh sebesar 3,078 dan nilai a (intercept) sebesar 0,008. Hal ini menunjukan bahwa pertumbuhan ikan pora-pora bersifat allometric positive, yaitu pertumbuhan berat lebih cepat daripada pertumbuhan panjang. Sesuai dengan pernyataan Effendie (2002), bahwa nilai yang lebih besar atau lebih kecil dari 3 pertumbuhan ikan dikatakan allometric. Jika nilai $\mathrm{b}<3$, maka pertambahan panjang ikan tersebut tidak seimbang dengan pertambahan beratnya. Pertambahan panjangnya lebih cepat dari pada pertambahan beratnya.Hubungan panjang dan berat ikan pora-pora yang diperoleh saat penelitian diperlihatkan pada Gambar 6 di bawah ini:

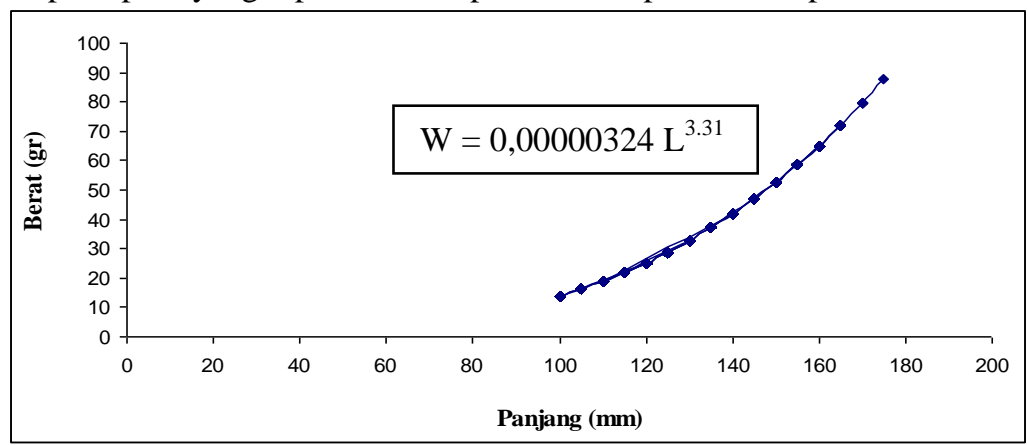

Gambar 6. Grafik Hubungan Panjang dan Berat Ikan Pora-Pora

\section{Faktor Kondisi}

Berdasarkan hasil analisa regresi data panjang berat ikan pora-pora, maka diperoleh nilai faktor kondisi ikan pora-pora $(\mathrm{Kn})$ sebesar 1,028. Hal tersebut berarti bahwa badan ikan kurus atau kurang montok. Hasil yang diperoleh sependapat dengan hasil penelitian Barus (2011) yang menyatakan bahwa nilai faktor kondisi (Kn) sebesar 1,137 yang berarti bahwa tubuh ikan pora-pora agak pipih. Dari hasil yang diperoleh saat penelitian, dapat diketahui bahwa ikan hasil tangkapan saat penelitian dalam kondisi lebih kurus dibandingkan dengan hasil penelitian terdahulu.

Perbedaan nilai Kn dikarenakan oleh beberapa faktor, yaitu pengaruh ketersediaan makanan, jenis kelamin, dan umur ikan yang berbeda. Perairan yang subur sangat menunjang kehidupan ikan dalam memperoleh makanan dan memungkinkan keberlangsungan populasi ikan (Asbar, 1994).

\section{Ukuran Pertama Kali Tertangkap}

Hasil penelitian diperoleh bahwa nilai panjang total tengah ikan adalah antara $98-173 \mathrm{~mm}$ dengan jumlah sampel sebanyak 10.486 ekor ikan pora-pora. Ukuran nilai tengah panjang total ikan yang mendominasi adalah $120 \mathrm{~mm}$. Struktur ukuran dari ikan pora-pora yang tertangkap selama penelitian di Danau Toba tersaji pada Gambar 7.
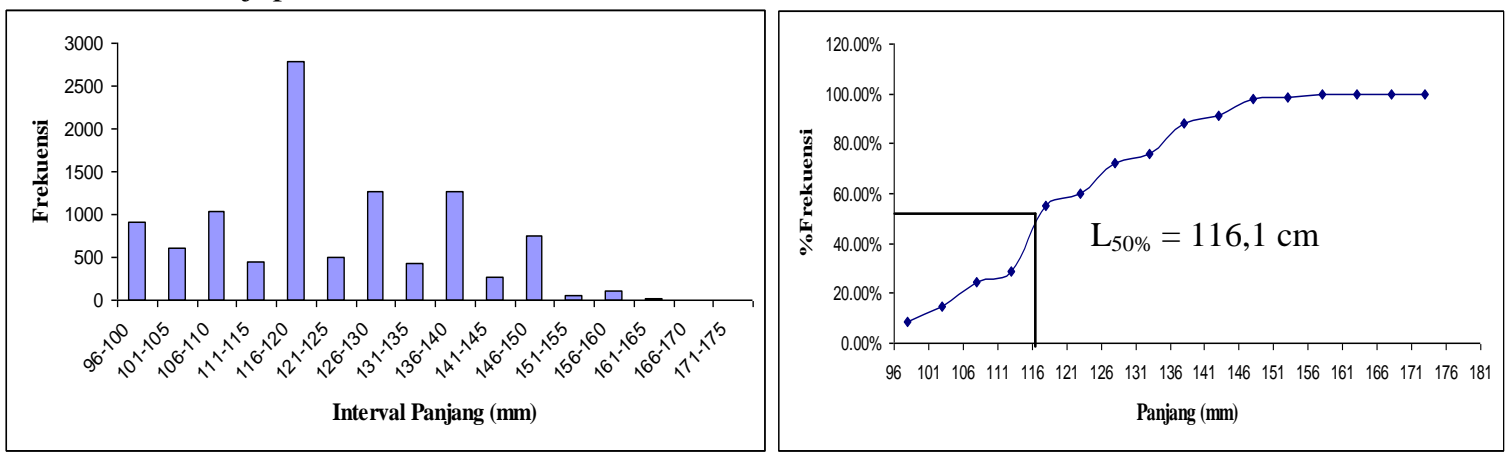

Gambar 7. Histogram Struktur dan Ukuran Pertama Kali Tertangkap Ikan Pora-Pora 
Dari hasil yang diperoleh, persebaran ukuran ikan pora-pora dari struktur ukuran membentuk suatu kurva. Ukuran ikan pora-pora yang tertangkap paling sedikit adalah pada kisaran kelas $171-175 \mathrm{~mm}$ dengan frekuensi 1 ekor. Sedangkan frekuensi panjang yang paling banyak tertangkap adalah pada kisaran 116 - 120 mm dengan jumlah 2790 ekor.

Dari hasil diketahui bahwa ukuran panjang rata-rata ikan pora-pora pertama kali tertangkap $\left(\mathrm{L}_{50 \%}\right)$

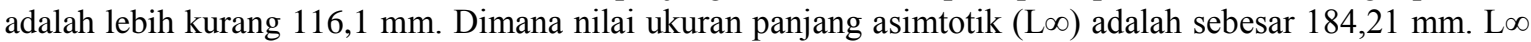
digunakan sebagai pembanding untuk melihat ukuran ikan yang tertangkap sudah cukup besar untuk dieksploitasi atau belum. Menurut Saputra (2009), L $\infty$ atau lebih sering disebut dengan ukuran maksimum yang mungkin dicapai oleh ikan yang lolos dari upaya penangkapan dan mampu bertahan dari mortalitas alami. Dari hasil penelitian, ukuran ikan pora-pora yang layak tangkap diperoleh dari $1 / 2$ L $\infty$ yaitu 92,105 $\mathrm{mm}$. Nilai $\mathrm{L}_{50 \%}>1 / 2 \mathrm{~L} \infty$ dengan nilai $116,1 \mathrm{~mm}>92,105 \mathrm{~mm}$. Dari hasil tersebut dapat diasumsikan bahwa ukuran ikan pora-pora yang tertangkap sudah cukup besar untuk dieksploitasi. Sesuai dengan pernyataan Saputra (2009), bahwa ukuran rata-rata ikan yang tertangkap pertama kali idealnya tidak lebih kecil dari setengah panjang infiniti $\left(1 / 2 \mathrm{~L}_{\infty}\right)$-nya. Hal ini berarti, dari sisi peluang reproduksi masih terjamin. Tingkat pemanfaatannya menunjukkan bahwa eksploitasi masih belum berlebihan.

\section{Selektivitas Alat Tangkap}

Faktor seleksi alat tangkap dan ukuran ikan yang pertama kali tertangkap alat penting diketahui karena sangat penting dalam pengelolaan sumberdaya perikanan. Dengan diketahuinya nilai $\mathrm{L}_{50 \%}$ dan ukuran mata jaring alat tangkap yang digunakan, maka dapat dihitung SF dari jaring alat tangkap tersebut. Apabila faktor selektivitas alat tangkap diperoleh, maka dapat dirumuskan saran tindak pengelolaan perikanan, khususnya terkait dengan pengaturan ukuran mata jaring agar ukuran ikan yang tertangkap mendekati keinginan pengelola (Saputra, 2009).

Mesh size alat tangkap doton yang digunakan sebagai alat tangkap ikan pora-pora di Danau Toba adalah $1 \frac{1}{4}$ inchi (dimana 1 inchi $=25,4 \mathrm{~mm}$ ) dengan nilai selektivitas 3,66 mm. Mesh size alat tangkap tanggok yang digunakan adlah sebesar $3 / 4$ inchi. Oleh karena itu, didapatkan nilai selektivitas alat tangkapnya adalah 6,09 $\mathrm{mm}$. Dari hasil diketahui bahwa, tingkat selektivitas alat tangkap tanggok lebih kecil dibandingkan alat tangkap doton. Hal tersebut dapat disimpulkan bahwa alat tangkap tanggok tidak selektif di dalam pengoperasiannya sehingga ikan-ikan kecil cenderung akan tertangkap.

\section{Aspek Pengelolaan}

Aspek pengelolaan yang perlu dilakukan untuk menjaga kelestarian sumberdaya ikan pora-pora adalah dengan cara mengatur alat tangkap yang ramah lingkungan, mengatur daerah penangkapan, dan mengatur jumlah lamanya penangkapan. Hal tersebut untuk pengelolaan berkelanjutan untuk melindungi spesies atau stok agar tidak terjadi overfishing.

Mesh size alat tangkap yang digunakan dalam penangkapan ikan pora-pora di Danau Toba sangat kecil sehingga tingkat selektivitasnya juga kecil. Dapat dikatakan bahwa alat tangkap tanggok lebih tidak selektif dibandingkan alat tangkap doton. Akibatnya banyak ikan pora-pora yang belum layak tangkap tertangkap oleh alat tangkap tanggok. Diduga laju eksploitasi ikan pora-pora di Danau Toba sangat tinggi, sehingga perlu dilakukan pengaturan terhadap penangkapan di kawasan perairan Danau Toba. Salah satunya dengan cara menggunakan alat tangkap yang selektif, yaitu dengan menggunakan ukuran mesh size alat tangkap yang besar. Seperti yang dikemukakan oleh Kartamihardja dan Sarnita (2010) bahwa alat tangkap yang digunakan dalam menangkap ikan pora-pora tidak boleh mempunyai ukuran mata jaring lebih kecil dari 1,25 inchi. Hal ini dilakukan untuk memberikan kesempatan bagi ikan pora-pora mencapai dewasa dan melakukan pemijahan. Umumnya ikan yang tertangkap dengan alat tangkap yang mesh size-nya kurang dari 1,25 inchi adalah ikan-ikan yang belum matang kelamin.

Penentuan daerah penangkapan ikan pora-pora juga perlu diperhatikan. Dimana, nelayan sekitar masih banyak yang melakukan penangkapan ikan pora-pora di daerah aliran sungai. Hal tersebut dapat mengakibatkan menurunnya jumlah produksi karena sungai merupakan daerah tempat pemijahan bagi ikan pora-pora. Apabila ikan pora-pora tersebut ditangkap sewaktu hendak beruaya ke daerah sungai, dimana ikan tersebut belum matang gonad, maka tidak akan terjadi pelestarian stok ikan yang baru.

\section{Kesimpulan dan Saran}

Kesimpulan yang dapat diperoleh dari hasil penelitian ini adalah sebagai berikut:

1. Nilai CPUE alat tangkap doton lebih kecil dibandingkan dengan CPUE alat tangkap tanggok dimana nilai rata-rata CPUE doton sebesar 1,64 kg/jam dengan rata-rata jumlah produksi $61 \mathrm{~kg}$ sedangkan nilai ratarata CPUE tanggok sebesar 4,72 kg/jam dengan rata-rata jumlah produksi $41 \mathrm{~kg}$;

2. Nilai "b" ikan pora-pora yang diperoleh dari penelitian sebesar 3,31 yang berarti bahwa pertambahan berat lebih cepat dibandingkan pertambahan panjang dengan nilai Kn sebesar 1,028 yang berarti bahwa badan ikan pora-pora kurus dan kurang montok; dan

3. Aspek pengelolaan yang dapat diberikan adalah dengan mengatur mesh size alat tangkap idak lebih kecil dari 1,25 inchi, guna memberikan kesempatan bagi ikan pora-pora mencapai dewasa dan melakukan pemijahan. 
Saran

1. Saran yang dapat diberikan adalah Perlu dilakukannya upaya pelestarian stok ikan yang terdapat di Danau Toba dengan cara mengatur besarnya mesh size alat tangkap yang digunakan, mengatur lokasi penangkapan ikan pora-pora, dan mengatur jumlah lamanya waktu penangkapan ikan pora-pora; dan

2. Perlu adanya penelitian lanjutan mengenai Tingkat Kematangan Gonad (TKG), Indeks Kematangan Gonad (IKG), faktor kebiasaan makan, dan daerah ruaya dari ikan pora-pora tersebut.

\section{Ucapan Terima Kasih}

Penulis mengucapkan terima kasih kepada Dr. Ir. Abdul Ghofar, M.Sc dan Dr. Ir. Pujiono Wahyu Purnomo, MS atas bimbingan dan arahan dalam penyusunan jurnal ini.

\section{Daftar Pustaka}

Ali, S. A. 2007. Kondisi Sediaan dan Keragaman Populasi Ikan Terbang (Hirundichtys oxychepalus Bleeker, 1852) di Laut Flores dan Selat Makassar. [Disertasi]. Program Pascasarjana Unhas. Makassar.

Asbar. 1994. Hubungan Tingkat Eksploitasi Dengan Struktur Populasi dan Produksi Udang Windu Penaeus monodon (F) di Segara Anakan.[Tesis]. Program Pascasarjana. Institusi Pertanian Bogor. Bogor.

Badrudin. 2010. Indeks Kelimpahan Stok dan Tingkat Pemanfaatan Sumberdaya Ikan Demersal di Wilayah Pengelolaan Perikanan Laut Jawa. [Riset Terapan]. Pusat Penelitian Pengelolaan Perikanan dan Konservasi Sumberdaya Ikan. Jakarta.

Barus, S. R. D. 2011. Aspek Bioekologi Ikan Bilih (Mystacoleucus padangensis Bleeker.) Di Perairan Danau Toba, Sumatera Utara. [Tesis]. Program Magister Biologi Fakultas Matematika dan Ilmu Pengetahuan Alam. Universitas Sumatera Utara. Medan.

Barus, T. A. 2007. Keanekaragaman Hayati Ekosistem Danau Toba dan Upaya Pelestariannya. [Pidato Pengukuhan Jabatan Guru Besar Tetap dalam Bidang Ilmu Limnologi]. Fakultas Matematika dan Ilmu Pengetahuan Alam. Universitas Sumatera Utara. Medan.

Barus, T. A. 2008. Produktivitas Primer Fitoplankton dan Hubungannya dengan Faktor Fisika Kimia Air di Perairan Parapat, Danau Toba. [Jurnal]. Departemen Biologi , Universitas Sumatera Utara. Medan.

Effendie, M. I. 2002. Biologi Perikanan. Yayasan Pustaka Nusatama. Yogyakarta.

Everhart, W. H dan W. D. Youngs. 1981. Principles of fishery science. 2nd Edition Comstock Publishing Associates, a division of Cornell University Press. Ithaca and London : $349 \mathrm{pp}$.

Hehanusa, P. E. 2000. Lake Toba, a multiple Caldera Depressio, North Sumatera, Indonesia. Report of Suwa Hydrobiological Station. Shinshu University. Japan.

Kartamihardja, E. S. dan Sarnita, A. S. 2010. Populasi Ikan Bilih di Danau Toba: Keberhasilan Introduksi Ikan Implikasi Pengelolaaan dan Prospek Masa Depan. Pusat Riset Perikanan Tangkap. Badan Riset Kelautan dan Perikanan. Departemen Kelautan Dan Perikanan.

Narbuko, C. dan A. Achmadi. 2009. Metodologi Penelitian. Bumi Aksara. Jakarta.

Notoatmodjo, S. 2002. Metodologi Penelitian Kesehatan. Rineka Cipta. Jakarta.

Purnomo, K dan Kartamihardja E. S. 2008. Keberhasilan Introduksi Ikan Bilih (Mystacoleucus padangensis) ke Habitatnya Yang Baru di Danau Toba, Sumatera Utara. [Prosiding Seminar Nasional Ikan IV]. Jatiluhur.

Ricker, W. E. 1975. Computation and Interpretation of Biological Statistics of Fish Populations. Buletin of Fisheries Research Board. Canada.

Saputra, S. W. 2009. Dinamika Populasi Ikan Berbasis Riset. Universitas Diponegoro. Semarang. 